\title{
PERTANGGUNGJAWABAN PARTAI POLITIK YANG MELAKUKAN TINDAK PIDANA KORUPSI*
}

\author{
Zainal Arifin Mochtar ${ }^{* *}$ \\ Departemen Hukum Administrasi Negara, \\ Fakultas Hukum, Universitas Gadjah Mada, \\ Jalan Sosio Justisia No. 1, Bulaksumur, Sleman, D.I.Yogyakarta 55281
}

\begin{abstract}
Political parties can be classified as legal entities that can be criminally responsible if they commit a corruption. However, even though there is a flow of funds from corruption based on the Corruption Eradication Commission's Indictment Letter, until now no political party has been convicted of committing a criminal act of corruption. This research aims to determine the accountability of political parties suspected of committing criminal acts of corruption. The results said that political parties are considered as legal subjects (rechtspersoon) whose actions can be carried out by party managers or others as long as they have a relationship with political parties. Types of punishment that can be applied to political parties that are suspected of committing corruption are various. One of them is dissolution. In the dissolution of political parties must also follow the regulation of dissolution of political parties in Indonesia.

Keywords: Criminal corruption responsibility, dissolution of political parties, regulation of dissolution of political parties.
\end{abstract}

\section{Intisari}

Partai politik dapat digolongkan sebagai korporasi berbadan hukum yang dapat bertanggung jawab secara pidana apabila melakukan tindak pidana korupsi. Namun demikian, meskipun terdapat aliran dana hasil korupsi berdasarkan Surat Dakwaan Komisi Pemberantasan Korupsi, tetapi sampai saat ini belum ada partai politik yang dipidana karena melakukan tindak pidana korupsi. Penelitian ini bertujuan untuk mengetahui pertanggungjawaban partai politik yang diduga melakukan tindak pidana korupsi. Hasil penelitian mengatakan, partai politik dianggap sebagai subjek hukum (rechtspersoon) yang tindakantindakannya dapat dilakukan oleh pengurus partai atau lainnya sepanjang memiliki hubungan dengan partai politik. Jenis pemidanaan yang dapat diterapkan ke partai politik yang diduga melakukan tindak pidana korupsi bermacam-macam. Salah satunya adalah pembubaran. Dalam pembubaran partai politik juga harus mengikuti regulasi pembubaran partai politik di Indonesia.

Kata Kunci: Pertanggungjawaban pidana korupsi, Pembubaran partai politik, Regulasi pembubaran partai politik.

\section{Pokok Muatan}

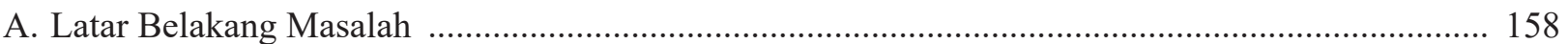

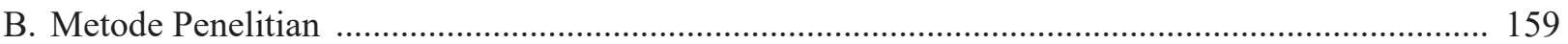

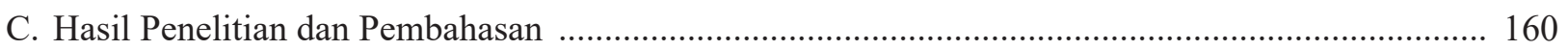

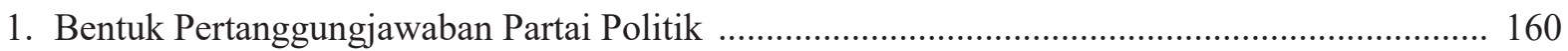

2. Pembubaran dan Pembekuan Partai Politik ...................................................................................... 162

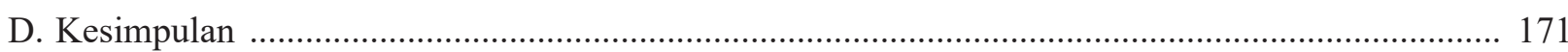

Hasil Penelitian yang didanai oleh Unit Riset dan Publikasi Fakultas Hukum Universitas Gadjah Mada pada tahun 2017. Penelitian dilaksanakan untuk mengikuti Program Penelitian Dosen Doktor Fakultas Hukum Universitas Gadjah Mada.

** Alamat korespondensi: zainalarifinmochtar@yahoo.com. 


\section{A. Latar Belakang Masalah}

Partai Politik diatur dalam Undang-Undang Nomor 2 Tahun 2008 tentang Partai Politik sebagaimana diubah dengan Undang-Undang Nomor 2 Tahun 2011 tentang Perubahan atas Undang-Undang Nomor 2 Tahun 2008 tentang Partai Politik (selanjutnya ditulis UU No. 2/2018 atau UU No. 2/2011), tergantung dari norma yang digunakan untuk menjelaskan atau menjadi dasar pernyataan dalam penelitian ini. Partai politik adalah organisasi yang bersifat nasional. ${ }^{1}$ Sebagai organisasi, partai politik dibentuk dengan mengikuti administrasi pembentukan badan hukum dengan syarat-syarat tertentu. Misalnya, partai politik harus didirikan oleh minimal 50 orang Warga Negara Indonesia (WNI) yang telah berumur 21 tahun dan mengakomodasi 30 persen jumlah keterwakilan perempuan. Kekurangan terhadap jumlah orang, batas minimal umur, dan rendahnya representasi perempuan akan membatalkan pembentukan partai politik. $^{2}$

Pendirian dan pembentukan partai politik dilakukan dengan akta notaris yang memuat Anggaran Dasar dan Anggaran Rumah Tangga Partai dengan substansi masing-masing. ${ }^{3}$ Partai politik yang telah didirikan dan dibentuk harus didaftarkan ke Kementerian Hukum dan Hak Asasi Manusia supaya menjadi badan hukum dengan memenuhi persyaratan tertentu. ${ }^{4}$ Berdasarkan konstruksi Pasal 1, Pasal 2, dan Pasal 3 UU No. 2/2011, maka Partai Politik dikategorikan sebagai badan hukum yang didirikan oleh sekelompok orang (WNI). Apabila dikaitkan dengan bunyi Pasal 1 angka 1
Undang-Undang Nomor 31 Tahun 1999 tentang Pemberantasan Tindak Pidana Korupsi (selanjutnya ditulis UU No. 31/1999), dimana "Korporasi adalah kumpulan orang dan/atau kekayaan yang terorganisasi baik merupakan badan hukum maupun bukan badan hukum" dan Pasal 1 angka 3 UU No. 31/1999 dimana "Setiap orang adalah orang perseorangan atau termasuk korporasi", maka partai politik dapat dimasukkan dalam jenis setiap orang yang dibebani pertanggungjawaban hukum tindak pidana korupsi apabila melakukan korupsi.

Fakta persidangan kasus korupsi penganggaran dan pengadan barang/jasa paket pengadaan penerapan Kartu Tanda Penduduk Berbasis Nomor Induk Kependudukan (KTP Elektronik) Tahun Anggaran 2011-2013 mengemukakan, ada aliran dana diduga hasil korupsi yang mengalir ke partai politik. Dalam Surat Dakwaan Komisi Pemberantasan Korupsi Republik Indonesia (KPK) bernomor DAK-15/24/02/2017 atas nama terdakwa Irman dan Sugiharto, keduanya adalah Pegawai Negeri Sipil di Kementerian Dalam Negeri, disebutkan ada aliran dana hasil korupsi ke Partai Golongan Karya sebesar Rp 150 miliar; Partai Demokrat (Rp 150 miliar); Partai Demokrasi Indonesia Perjuangan (Rp 80 miliar); dan partaipartai lainnya (Rp 80 miliar). ${ }^{5}$ Meskipun disebutkan dalam Surat Dakwaan KPK, tetapi hingga saat ini belum ada satupun partai politik yang diajukan ke persidangan tindak pidana korupsi atas dugaan aliran dana hasil korupsi tersebut. Berdasarkan uraian tersebut, rumusan masalah dalam penelitian ini antara lain: (1) dalah, Pertama, Bagaimana

Pasal 1 angka 1 Undang-Undang Nomor 2 Tahun 2011 tentang Perubahan atas Undang-Undang Nomor 2 Tahun 2008 tentang Partai Politik menyatakan, "Partai Politik adalah organisasi yang bersifat nasional dan dibentuk oleh sekelompok Warga Negara Indonesia secara sukarela atas dasar kesamaan kehendak dan cita-cita untuk memperjuangkan dan membela kepentingan politik anggota, masyarakat, bangsa dan negara, serta memelihara keutuhan Negara Kesatuan Republik Indonesia berdasarkan Pancasila dan Undang-Undang Dasar Negara Republik Indonesia Tahun 1945,"

Lihat Pasal 2 ayat (1) dan ayat (2) UU No. 2/2008, Lembaran Negara Republik Indonesia Tahun 2008 Nomor 2, Tambahan Lembaran Negara Republik Indonesia Nomor 4801.

Pasal 1 angka 4 Undang-Undang Nomor 2 Tahun 2011 tentang Perubahan atas Undang-Undang Nomor 2 Tahun 2008 tentang Partai Politik menyebutkan Anggaran Dasar Partai Politik meliputi, "asas dan ciri partai politik; visi dan misi partai politik; nama, lambang, dan tanda gambar partai politik; tujuan dan fungsi partai politik; organisasi, tempat kedudukan, dan pengambilan keputusan; kepngurusan partai politik; mekanisme rekrutmen keanggotaan partai politik dan jabatan politik; sistem kaderisasi; mekanisme pemberhentian anggota partai politik; peraturan dan jenis keputusan partai politik; pendidikan politik; keuangan partai politik; dan mekanisme penyelesaian perselisihan internal partai politik."

Lihat Pasal 3 UU No. 2/2011, Lembaran Negara Republik Indonesia Tahun 2011 Nomor 8, Tambahan Lembaran Negara Republik Indonesia Nomor 5189.

Surat Dakwaan KPK Nomor DAK-15/24/02/2017, hlm 12-13. 
pertanggungjawaban partai politik yang diduga melakukan tindakan pidana korupsi; dan (2) Bagaimana. Kedua, pembubaran yang dapat diterapkan ke partai politik yang diduga melakukan tindak pidana korupsi. Ketiga, desain ideal pembubaran partai politik.

\section{B. Metode Penelitian}

Jenis penelitian ini menggunakan metode penelitian yuridis-normatif. Keterangan tentang bentuk pertanggungjawaban partai politik yang diduga melakukan korupsi diperoleh dari norma peraturan perundang-undangan, yakni (1) Kitab Undang-Undang Hukum Pidana (KUHP), (2) UU No. 31/1999, (3) Undang-Undang Nomor 20 Tahun 2001 tentang Perubahan Atas UU No. 31/1999 (selanjutnya ditulis UU No. 20/2001).

Keterangan tentang jenis pemidanaan yang dapat diterapkan ke partai politik yang diduga melakukan tindak pidana korupsi diperoleh dari peraturan perundang-undangan meliputi, (1) Ketetapan MPRS Nomor VVV/MPRS/1966 tentang Pembubaran Partai Komunis Indonesia, (2) Pernyataan Sebagai Organisasi Terlarang di Seluruh Wilayah Indonesia bagi Partai Komunis Indonesia dan Larangan Setiap Kegiatan atau Menyebarkan atau Mengembangkan Faham atau Ajaran Komunisme/Marxisme/Leninisme, (3) UU No. 31/1999, (4) UU No. 20/2001, (5) UndangUndang Nomor 24 Tahun 2003 tentang Mahkamah Konstitusi (selanjutnya ditulis UU No. 24/2003), (6) UU No. 2/2008, (7) UU No. 2/2011, (8) UndangUndang Nomor 8 Tahun 2011 tentang Perubahan Atas UU No. 24/2003, (9) Penetapan Presiden Nomor 7 Tahun 1959 tentang Syarat-syarat dan Penyederhanaan Kepartaian (selanjutnya ditulis Penpres No. 7/1959), (10) Peraturan Presiden Nomor 13 Tahun 1960 tentang Pengakuan, Pengawasan, dan Pembubaran Partai-Partai (selanjutnya ditulis Perpres No. 13/1960), (11) Peraturan Presiden Nomor 25 Tahun 1960 tentang Perubahan Atas Perpres No. 13/1960 tentang Pengakuan, Pengawasan, dan Pembubaran Partai Politik (selanjutnya ditulis Perpres 25/1960), (12)
Keputusan Presiden Nomor 200 Tahun 1960 tentang Pembubaran Partai Masyumi (selanjutnya ditulis Keppres No. 200/1960); (13) Keputusan Presiden Nomor 201 Tahun 1960 tentang Pembubaran Partai Sosialis Indonesia (selanjutnya ditulis Keppres No. 201/1960), (14) Keputusan Presiden Nomor 291 Tahun 1965 tentang Pembekuan terhadap Partai Murba (selanjutnya ditulis Keppres No. 291/1965), (15) Peraturan Mahkamah Konstitusi Nomor 12 Tahun 2008 tentang Prosedur Beracara dalam Pembubaran Partai Politik (selanjutnya ditulis Peraturan MK No. 12/2008), dan (16) Peraturan Mahkamah Agung Nomor 13 Tahun 2016 tentang Tata Cara Penanganan Perkara Tindak Pidana oleh Korporasi (selanjutnya ditulis Peraturan MA No. 13/2016).

Sedangkan buku, hasil penelitian, dan jurnal yang menjadi rujukan untuk mengetahui bentuk pertanggungjawaban partai politik yang diduga melakukan korupsi serta jenis pemidanaan yang dapat diterapkan ke partai politik yang diduga melakukan tindak pidana korupsi adalah (1) Muchammad Ali Safa'at, 2001, Pembubaran Partai Politik, Pengaturan dan Praktik Pembubaran Partai Politik Dalam Pergulatan Republik, Raja Grafindo Persada, Jakarta, (2) Jimly Asshiddiqie, 2005, Kemerdekaan Berserikat, Pembubaran Partai Politik, dan Mahkamah Konstitusi, Konstitusi Pers, Jakarta, (3) Widayati, Pembubaran Partai Politik Dalam Sistem Ketatanegaraan Indonesia, Jurnal Hukum, Vol. XXXVI, No. 2, Agustus 2011, (4) Hifdzil Alim, dkk, 2013, Pemidanaan Korporasi atas Tindak Pidana Korupsi di Indonesia, Pusat Kajian Antikorupsi FH UGM, Yogyakarta, dan (5) Eddy O.S. Hiariej, 2018, Prinsip-prinsip Hukum Pidana, Cahaya Atma Pustaka, Yogyakarta.

Peraturan perundang-undangan lainnya, buku-buku, jurnal, hasil penelitian, dan kamus hukum juga dirujuk untuk mendapatkan informasi yang berkaitan dengan bentuk pertanggungjawaban partai politik yang diduga melakukan korupsi dan jenis pemidanaan yang dapat diterapkan ke partai politik yang diduga melakukan tindak pidana korupsi. 


\section{Hasil Penelitian dan Pembahasan}

1. Bentuk Pertanggungjawaban Partai Politik

Konstruksi Pasal 1 angka 1 dan angka 3 UU No. 31/1999 menempatkan korporasi sebagai subjek hukum pidana. ${ }^{6}$ Korporasi yang disebutkan dalam UU No. 31/1999 termasuk badan hukum maupun bukan badan hukum. Sesuai dengan bunyi Pasal 1 angka 1 dan Pasal 3 ayat (1) UU No. 2/2011, partai politik dimaknai sebagai organisasi berbadan hukum. Dengan demikian, partai politik dapat dimasukkan dalam kelompok korporasi berbadan hukum yang dalam hal ini menjadi subjek hukum pidana, sehingga partai politik sebagai korporasi berbadan hukum dapat diperiksa apabila diduga melakukan tindak pidana korupsi. ${ }^{?}$

\section{Ketentuan bahwa korporasi dianggap} melakukan tindak pidana karena orang-orang, baik yang memiliki hubungan kerja atau hubungan lainnya, bertindak untuk dan atas nama atau dalam lingkungan korporasi sebagaimana diatur dalam Pasal 20 ayat (2) UU No. 31/1999 juga ditemukan dalam peraturan perundang-undangan lainnya. Pasal 15 ayat (2) Undang-Undang Darurat Nomor 7 Tahun 1955 tentang Pengusutan, Penuntutan, dan Peradilan Tindak Pidana Ekonomi (selanjutnya ditulis UU No. 7/1955). ${ }^{8}$

Konsep tentang frasa "dilakukan oleh orang baik sendiri atau bersama-sama berdasarkan hubungan kerja atau hubungan lainnya" dalam Pasal 15 ayat (2) UU No. 7/1955 menunjukkan harus dilakukan dalam orang yang berada di dalam lingkup memiliki hubungan kerja dengan korporasi.
Sedangkan "hubungan lain" dapat dicontohkan dengan orang-orang yang mewakili korporasi untuk menjual barang-barang dari korporasi dengan mendapatkan komisi (commisie agent). ${ }^{9}$ Dengan demikian, setiap tindak pidana yang dilakukan oleh perorangan yang dalam lingkup hubungan kerja maupun hubungan lainnya dengan korporasi, maka tindak pidana tersebut dianggap sebagai tindak pidana yang dilakukan oleh korporasi.

Konsep korporasi yang diterapkan ke partai politik sebagai subjek hukum pidana mengikuti asas tiada pidana tanpa kesalahan (geen straf zonder schuld). Setiap perbuatan pidana mensyaratkan adanya kesalahan. Ada empat teori yang dapat digunakan untuk menerapkan konsep korporasi pada partai politik sebagai subjek hukum pidana.

Pertama, teori pelaku fungsional (functioneel daaderschap). Pidana dilakukan oleh orang yang memiliki hubungan kerja dengan partai politik sepanjang masih dalam ruang Anggaran Dasar dan Anggran Rumah Tangga yang diatur dalam partai politik. Kedua, teori identifikasi. Partai politik dapat melakukan pidana secara langsung melalui orangorang yang memiliki hubungan sangat erat dengan partai politik atau dipandang sebagai partai politik itu sendiri. Ketiga, teori vicarious liability. Teori yang dikembangkan dari employment principle, yakni majikan adalah penanggung jawab utama dari perbuatan buruh/karyawan. Partai politik adalah penanggung jawab utama dari perbuatan anggota dan kadernya. Keempat, teori strict liability. Partai politik dianggap bertanggung jawab apabila melanggar perintah peraturan perundang-

Korporasi menjadi subjek hukum pidana di Indonesia mulai dikenal pada tahun 1951 melalui Undang-Undang tentang Penimbunan Barang. Diikuti kemudian oleh Undang-Undang tentang Tindak Pidana Ekonomi; UU Subversi; UU Narkotika; UU Psikotropika; UU Lingkungan Hidup; UU Tipikor; dan UU TPPU. Lihat, Muladi, et al. 2010, Pertanggungjawaban Pidana Korporasi, Kencana Prenada Media, Jakarta, hlm 46.

Sebagai informasi, dalam Hukum Belanda, badan hukum ditempatkan sebagai subjek hukum pidana terjadi pada 1 September 1976 . Pasal 51 KUHP Belanda mencantumkan ketentuan bahwa apabila sebuah tindak pidana dilakukan oleh badan hukum, maka tuntutan pidana dapat dijatuhkan kepada (1) badan hukum itu sendiri; (2) orang yang memerintahkan serta yang secara nyata memimpin laku perbuatan; dan (3) dijatuhkan secara bersama-sama terhadap badan hukum itu sendiri dan orang yang memerintahkan atau secara nyata memimpin laku perbuatan. Lihat, Schaffmeister, N. Keijzer, dan E.H.P Sutorius, et al, 2010, Hukum Pidana, Citra Aditya Bakti, Bandung, hlm 257.

Pasal 15 ayat (2) Undang-Undang Darurat Nomor 7 Tahun 1955 tentang Pengusutan, Penuntutan dan Peradilan Tindak Pidana Ekonomi menyatakan, "Suatu tindak pidana ekonomi dilakukan juga oleh atau atas nama suatu badan hukum, suatu perseroan, suatu perserikatan orang atau yayasan, jika tindak itu dilakukan oleh orang-orang yang baik berdasar hubungan kerja maupun berdasar hubungan lain, bertindak dalam lingkungan badan hukum, perseroan, perserikatan atau yayasan itu, tak peduli apakah orang-orang itu masing-masing tersendiri melakukan tindak pidana ekonomi itu atau pada mereka bersama ada anasir-anasir tindak pidana tersebut.”

Muladi, et al., Op. cit., hlm 95. 
undangan. ${ }^{10}$

Batasan tentang korporasi berbadan hukum dapat diperiksa karena diduga melakukan korupsi diatur dalam Pasal 20 UU No. 31/1999, yaitu:

a. Dalam hal korupsi dilakukan untuk dan atas nama korporasi, maka tuntutan dan penjatuhan pidana dilakukan terhadap korporasi dan/atau pengurusnya;

b. Korupsi dilakukan oleh korporasi apabila korupsi tersebut dilakukan oleh orang-orang yang baik atas hubungan kerja maupun hubungan lainnya, bertindak dalam lingkungan korporasi baik sendiri-sendiri maupun bersama-sama;

c. Tuntutan pidana terhadap korporasi diwakili oleh pengurusnya;

d. Pengurus yang mewakili korporasi dapat diwakili oleh orang lain;

e. Hakim dapat memerintahkan supaya pengurus korporasi menghadap sendiri ke pengadilan atau hakim memerintahkan agar pengurus yang mewakili korporasi dihadapkan ke sidang pengadilan;

f. Penyerahan untuk surat panggilan menghadap bagi korporasi yang dituntut pidana disampaikan ke pengurus di tempat tinggal pengurus atau kantor pengurus; dan

g. Pidana pokok yang dijatuhkan terhadap korporasi hanya pidana denda dengan ketentuan maksimum pidana ditambah sepertiga $(1 / 3)$.

Selain pidana pokok yang diatur dalam Pasal 20 ayat (2) UU No. 31/1999, diatur pula pidana tambahan dalam Pasal 18 ayat (1) UU No. 31/1999. Pidana tambahan yang dimaksud adalah:

a. Perampasan barang bergerak baik yang berwujud atau tidak berwujud yang digunakan untuk atau yang diperoleh dari hasil korupsi, termasuk perusahaan milik terpidana dimana korupsi dilakukan, begitu pula barang yang menggantikan barang-barang tersebut;

b. Pembayaran uang pengganti yang jumlahnya sebanyak-banyaknya sama dengan harta benda yang diperoleh dari tindak pidana korupsi;

c. Penutupan seluruh atau sebagian perusahaan untuk waktu paling lama satu tahun; dan

d. Pencabutan seluruh atau sebagian hakhak tertentu atau penghapusan seluruh atau sebagian keuntungan tertentu, yang telah atau dapat diberikan oleh pemerintah kepada terpidana.

Dengan mengikuti ketentuan Pasal 20 UU

No. 31/1999, maka pertanggungjawaban partai

politik yang diduga melakukan tindak pidana

korupsi diterapkan dalam tabel sebagai berikut:

Tabel 1.

Pertanggungjawaban Partai Politik

Berdasarkan Pasal 20 UU No. 31/1999

\begin{tabular}{|c|c|c|c|}
\hline No & Pelaku Korupsi & $\begin{array}{l}\text { Pertanggung- } \\
\text { jawaban }\end{array}$ & $\begin{array}{l}\text { Dasar } \\
\text { Hukum }\end{array}$ \\
\hline 1. & $\begin{array}{l}\text { Pengurus, kader, } \\
\text { dan anggota } \\
\text { partai atas nama } \\
\text { partai politik. }\end{array}$ & $\begin{array}{l}\text { Pidana } \\
\text { terhadap } \\
\text { partai politik. }\end{array}$ & $\begin{array}{l}\text { Pasal } 20 \\
\text { ayat (1) }\end{array}$ \\
\hline 2. & $\begin{array}{l}\text { Pengurus, kader, } \\
\text { dan anggota } \\
\text { partai atas nama } \\
\text { partai politik. }\end{array}$ & $\begin{array}{l}\text { Pidana terha- } \\
\text { dap pengurus, } \\
\text { kader, dan } \\
\text { anggota partai } \\
\text { politik. }\end{array}$ & $\begin{array}{l}\text { Pasal } 20 \\
\text { ayat (1) }\end{array}$ \\
\hline 3. & $\begin{array}{l}\text { Pengurus, kader, } \\
\text { dan anggota } \\
\text { partai atas nama } \\
\text { partai politik. }\end{array}$ & $\begin{array}{l}\text { Pidana ter- } \\
\text { hadap partai } \\
\text { politik serta } \\
\text { pengurus, } \\
\text { kader, dan } \\
\text { anggotanya. }\end{array}$ & $\begin{array}{l}\text { Pasal } 20 \\
\text { ayat (1) }\end{array}$ \\
\hline 4. & $\begin{array}{l}\text { Pengurus, kader, } \\
\text { anggota partai } \\
\text { politik atau } \\
\text { orang-orang } \\
\text { yang memiliki } \\
\text { hubungan } \\
\text { dengan partai } \\
\text { politik baik } \\
\text { secara sendiri- } \\
\text { sendiri maupun } \\
\text { bersama-sama. }\end{array}$ & Partai politik. & $\begin{array}{l}\text { Pasal } 20 \\
\text { ayat (2) }\end{array}$ \\
\hline
\end{tabular}

Sumber: Diolah oleh Penulis, 2018. 


\section{Pembubaran dan Pembekuan Partai Politik}

Penjelasan mengenai pembubaran dan pembekuan partai politik ini, akan dibagi dalam 3 (tiga) periode pemerintahan, yakni masa orde lama, orde baru, dan reformasi.

\section{a. Masa Orde Lama}

Pada era Presiden Soekarno, pembubaran partai politik diatur dalam Penetapan Presiden Nomor 7 Tahun 1959 tentang Syarat-syarat dan Penyederhanaan Kepartaian (selanjutnya ditulis Penpres No. 7/1959). Dalam Pasal 9 ayat (1) Perpres No. 7/1959 pada pokoknya disebutkan, "Presiden setelah mendengar Mahkamah Agung dapat melarang dan/atau membubarkan partai yang:

1) bertentangan dengan asas dan tujuan negara;

2) programnya bermaksud merombak asas dan tujuan negara;

3) sedang melakukan pemberontakan karena pemimpin-pemimpinnya turut serta dalam pemberontakan-pemberontakan atau telah jelas memberikan bantuan, sedangkan partai itu tidak dengan resmi menjalankan perbuatan anggota-anggotanya itu;

4) tidak memenuhi syarat-syarat lain yang ditentukan dalam Penetapan Presiden ini. ${ }^{11}$

Pembubaran partai pada era Soekarno melalui Penpres No. 7/1959 berada di tangan Presiden. Kewenangan pengawasan dan pemeriksaan partai politik terhadap partai ada di tangan Presiden. ${ }^{12}$ Pembubaran partai politik berada di tangan Presiden. Setahun kemudian, pemerintah menerbitkan Peraturan Presiden Nomor 13 Tahun 1960 tentang
Pengakuan, Pengawasan, dan Pembubaran Partai Politik selanjutnya ditulis Perpres No. 13/1960, yang kemudian diubah dengan Peraturan Presiden Nomor 25 Tahun 1960. Dalam perpres tersebut, jika sebuah partai politik disangka memenuhi syarat untuk dibubarkan - seperti disebutkan dalam Pasal 9 ayat (1) Penpres No. 7/1959—Presiden menyampaikan hal tersebut ke Mahkamah Agung (MA) dengan semua dokumen untuk pembuktian. Selanjutnya, MA memeriksa sangkaan tersebut dengan acara bebas dan kemudian menyampaikan pendapatnya berdasarkan hasil pemeriksaan kepada Presiden.

Dalam waktu paling lambat 30 hari setelah diterbitkan Keputusan Presiden tentang pembubaran partai politik, pimpinan partai politik harus menyampaikan kepada Presiden bahwa partai politiknya telah bubar. Jika tidak bubar, maka partai politik tersebut dianggap sebagai perkumpulan terlarang. Partai politik yang telah bubar berakibat pada anggotanya. Dalam Pasal 9 Perpres No. 13/1960 disebutkan:

"sebagai akibat pembubaran/pelarangan sesuatu partai, seorang anggota dari partai itu yang duduk sebagai anggota Majelis Permusyawaratan Rakyat, Dewan Perwakilan Rakyat atau Dewan Perwakilan Rakyat Daerah dianggap berhenti sebagai anggota badan-badan tersebut."

Di era Presiden Soekarno, terdapat dua partai yang dibubarkan, yakni, Partai Masyumi dan Partai Sosialis Indonesia (PSI), serta satu partai yang dibekukan, Partai Murba. Alasan pembubaran Partai Masyumi tampaknya didesain secara politik oleh Presiden Soekarno. ${ }^{13}$ Terdapat empat

11 Persyaratan lain yang ditetapkan terdapat dalam Pasal 2 sampai dengan Pasal 6 Penetapan Presiden Nomor 7 Tahun 1959 meliputi (i) idiologi partai politik; (ii) asas partai politik; (iii) tujuan partai politik; (iv) program partai politik; (v) kegiatan partai politik; (vi) jumlah dan syarat keanggotaan partai politik; dan (vii) pendanaan partai politik.

12 Lihat Pasal 8 Penetapan Presiden Nomor 7 Tahun 1959 (Lembaran Negara dan Tambahan Lembaran Negara Tahun 1959 yang telah dicetak ulang).

13 Lihat, Jimly Asshiddiqie, 2005, Kemerdekaan Berserikat, Pembubaran Partai Politik, dan Mahkamah Konstitusi, Konstitusi Press, Jakarta, hlm 180. Deliar Noer, 1987, Partai Islam di Pentas Nasional 1945-1965, Pustaka Utama Grafiti, Jakarta, hlm 384. 
pertanyaan yang diajukan oleh Presiden Soekarno terkait dengan rencana pembubaran Partai Masyumi dan PSI. Pertama, apakah partai-partai itu menentang dasar dan tujuan negara? Kedua, apakah partaipartai itu bermaksud mengubah dasar dan tujuan negara? Ketiga, apakah partai-partai itu berhubungan dengan pemberontakan Pemerintahan Revolusioner Republik Indonesia (PPRI)? Keempat, apakah partaipartai itu memenuhi persyaratan kepartaian yang diatur dalam Penpres No. 7/1959. ${ }^{14}$

Terhadap pertanyaan yang diajukan oleh Presiden Soekarno, jawaban yang disampaikan oleh petinggi Partai Masyumi dan PSI dinilai tidak memuaskan oleh Presiden Soekarno. Selanjutnya, pada tanggal 17 Agustus 1960, Presiden Soekarno menerbitkan Keputusan Presiden Nomor 200 Tahun 1960 tentang Pembubaran Partai Masyumi dan Keputusan Presiden Nomor 201 Tahun 1960 tentang Pembubaran Partai Sosialis Indonesia (PSI). ${ }^{15}$ Presiden Soekarno ketika menyampaikan amanat presiden pada ulang tahun Proklamasi Kemerdekaan Indonesia pada 17 Agustus 1960 menyatakan bahwa pembubaran Partai Masyumi dan PSI karena kedua partai tersebut dianggap melanggar ketentuan Pasal 9 Penpres No. 7/1959. Pada 13 September 1960, pimpinan pusat Partai Masyumi menyatakan partainya bubar. Pernyataan tersebut dipandang lebih baik dari pada bubar dengan sendirinyaberdasarkan norma Perpres No. 13/1960 jo Perpres No. 25/1960 dan dinyatakan sebagai partai terlarang. Apabila bubar dengan sendirinya dan dinyatakan sebagai partai terlarang, maka akan menyulitkan anggotaanggotanya. ${ }^{16}$ Juga ditakutkan karena dianggap partai terlarang, maka harta benda dan dokumen dokumen partai akan disita oleh negara. ${ }^{17}$

Pembekuan partai politik pada era orde lama dilakukan terhadap Partai Murba. Presiden Soekarno membekukan Partai Murba pada 5 Januari 1965 akibat konflik antarpartai politik, terutama antara Partai Komunis Indonesia (PKI) dengan partaipartai yang menolak keberadaan PKI. Gesekan PKI dengan Partai Murba diawali dengan ditemukannya dokumen rahasia PKI yang berjudul "Resume Program dan Kegiatan PKI Dewasa ini”. Pada intinya, dokumen tersebut berisi tentang rencana PKI merebut pimpinan revolusi dari tangan kaum borjuis. ${ }^{18}$ Dokumen rahasia PKI itu jatuh ke tangan Partai Murba. Tokoh Partai Murba yang juga Wakil Perdana Menteri Chairul Saleh, menyerahkan dokumen tersebut ke Perdana Menteri sekaligus Ketua Partai Nasionalis Indonesia (PNI) Ali Sastroamidjojo. Kemudian Ali Sastroamidjojo menyampaikan perihal dokumen PKI itu dalam sidang kabinet bulan Desember 1964. PKI menyampaikan bantahan dan menganggap perihal dokumen tersebut sebagai buatan kaum trotskis yang dibantu oleh kekuatan neokolonialisme untuk menghancurkan PKI. ${ }^{19}$

PKI dapat meyakinkan Presiden Soerkarno bahwa dokumen rahasia itu palsu. Presiden Soekarno kemudian memanggil para petinggi partai politik ke Istana Bogor dan meminta agar para petinggi partai 
menyelesaikan sengketa antarpartai. Pada 12 Desember 1964, sepuluh partai politik menandatangani "Deklarasi Bogor" yang menganggap persoalan dokumen rahasi tersebut selesai dan memelihara persatuan nasional atas dasar Pancasila, Manipol USDEK, dan rumusan Nasakom. ${ }^{20}$ Pada 5 Januari 1965, PresidenSoekarnomembekukan Partai Murba melalui Keputusan Pres Nomor 291 Tahun 1965 tentang Pembekuan terhadap Partai Murba. Pembekuan Partai Murba tidak pernah dicairkan sampai akhir kepemimpinan Presiden Soekarno. ${ }^{21}$

b. Masa Orde Baru

Pembubaran partai politik dilakukan terhadap PKI. Sedangkan pembekuan partai politik dilakukan terhadap Pertindo. Pembubaran PKI didasarkan pada pertimbangan bahwa PKI melancarkan serangkaian tindakan dalam sebuah "Gerakan 30 September". PKI melancarkan aksi gelap berupa fitnah, hasutan, desas-desus, adu domba, sampai upaya pembentukan Angkatan Bersenjata. Aksi PKI itu dianggap mengakibatkan terganggunya keamanan rakyat dan ketertiban. Pertimbangan pembubaran lainnya adalah putusan Mahkamah Militer Luar Biasa yang menjatuhkan hukum ke tokoh-tokoh Gerakan 30 September. ${ }^{22}$

Pembubaran PKI dituangkan dalam Keputusan Presiden Nomor 1/3/1966 tentang Pembubaran Partai Komunis Indonesia (PKI). Keputusan pembubaran tersebut dikukuhkan dengan Ketetapan MPRS Nomor XXV/MPRS/1966 tentang Pembubaran Partai Komunis Indonesia, Pernyataan Sebagai Organisasi Terlarang Diseluruh Wilayah Indonesia bagi Partai Komunis
Indonesia dan Larangan Setiap Kegiatan atau Menyebarkan atau Mengembangkan Faham atau Ajaran Komunisme/Marxisme/ Leninisme (selanjutnya ditulis Tap MPRS No. XXV/MPRS/1966) yang diterbitkan pada tanggal 5 Juli 1966. Tap MPRS No. XXV/MPRS/1966 menyebutkan alasan pembubaran PKI sebagai berikut:

1) faham atau ajaran komunisme/ marxisme/leninisme bertentangan dengan Pancasila; dan

2) orang-orang dan golongangolongan di Indonesia yang menganut faham atau ajaran komunisme/marxisme/leninisme, khususnya PKI, nyatanyata terbukti beberapa kali berusaha merobohkan kekuasaan Pemerintah Republik Indonesia yang sah dengan jalan kekerasan.

Pemerintah Orde Baru melakukan pembekuan terhadap Pertindo karena menganggap Pertindo memiliki kedekatan dengan PKI. Presiden Soeharto menilai Kongres Pertindo pada Januari 1964 telah menyetujui resolusi-resolusi yang isinya mirip dengan program PKI. ${ }^{23}$ Pembubaran PKI dan pembekuan Pertindo tidak melalui mekanisme peradilan. Sebaliknya, Pemerintah Orde Baru mengedepankan upaya-upaya kekuasaan. Pembubaran dan pembekuan ini dinilai tidak mencerminkan negara hukum dan demokrasi dimana seharusnya setiap keputusan pembubaran partai harus diawali dengan proses peradilan berdasarkan prinsip due procces of law dan fair trial. ${ }^{24}$ 
c. Masa Era Reformasi

Di era reformasi, negara menerbitkan

UU No. 2/2008 jo UU No. 2/2011. Larangan bagi partai politik diatur. Sanksi pelanggaran terhadap larangan diatur berjenjang. Ketentuan tentang pembubaran dan pembekuan partai politik diatur. Larangan terhadap partai politik dapat berimplikasi pada larangan yang bersifat administrasi maupun pidana. Merujuk pada ketentuan sanksi terhadap partai politik sebagaimana diatur Bab XIX tentang Sanksi dalam UU No. 2/2008 jo UU No. 2/2011 (Pasal 47, Pasal 48, Pasal 49, dan Pasal 50), maka sanksi yang dapat diterapkan ke partai politik-tidak kepada pengurusnya-yang melakukan pelanggaran sebagaimana diatur dalam UU No. 2/2008 jo UU No. 2/2011 ditampilkan dalam tabel sebagai berikut:

\section{Tabel 2}

Bagi Partai Politik Dalam UU No. 2/2008 jo UU No. 2/2011

\begin{tabular}{|c|c|c|c|c|}
\hline No. & Jenis Pelanggaran & $\begin{array}{c}\text { Dasar } \\
\text { Hukum }\end{array}$ & Jenis Sanksi & $\begin{array}{l}\text { Dasar } \\
\text { Hukum }\end{array}$ \\
\hline 1. & $\begin{array}{l}\text { Melanggar syarat pembentukan } \\
\text { partai politik }\end{array}$ & Pasal 2 & $\begin{array}{l}\text { Sanksi administratif berupa } \\
\text { penolakan pendaftaran partai } \\
\text { politik sebagai badan hukum oleh } \\
\text { Kementerian Hukum dan HAM }\end{array}$ & $\begin{array}{l}\text { Pasal } 47 \\
\text { ayat (1) }\end{array}$ \\
\hline 2. & $\begin{array}{l}\text { Melanggar syarat pendaftaran } \\
\text { partai politik sebagai badan } \\
\text { hukum }\end{array}$ & Pasal 3 & $\begin{array}{l}\text { Sanksi administratif berupa } \\
\text { penolakan pendaftaran partai } \\
\text { politik sebagai badan hukum oleh } \\
\text { Kementerian Hukum dan HAM }\end{array}$ & $\begin{array}{l}\text { Pasal } 47 \\
\text { ayat (1) }\end{array}$ \\
\hline 3. & $\begin{array}{l}\text { Asas partai politik bertentangan } \\
\text { dengan Pancasila dan UUD } \\
1945\end{array}$ & $\begin{array}{l}\text { Pasal } 9 \text { ayat } \\
\text { (1) }\end{array}$ & $\begin{array}{l}\text { Sanksi administratif berupa } \\
\text { penolakan pendaftaran partai } \\
\text { politik sebagai badan hukum oleh } \\
\text { Kementerian Hukum dan HAM }\end{array}$ & $\begin{array}{l}\text { Pasal } 47 \\
\text { ayat (1) }\end{array}$ \\
\hline 4. & $\begin{array}{l}\text { Partai politik menggunakan } \\
\text { nama, lambang, tanda gambar } \\
\text { Pemerintah Indonesia }\end{array}$ & $\begin{array}{l}\text { Pasal } 40 \text { ayat } \\
\text { (1) }\end{array}$ & $\begin{array}{l}\text { Sanksi administratif berupa } \\
\text { penolakan pendaftaran partai } \\
\text { politik sebagai badan hukum oleh } \\
\text { Kementerian Hukum dan HAM }\end{array}$ & $\begin{array}{l}\text { Pasal } 47 \\
\text { ayat (1) }\end{array}$ \\
\hline 5. & $\begin{array}{l}\text { Partai politik tidak membuat } \\
\text { pembukuan keuangan }\end{array}$ & $\begin{array}{l}\text { Pasal } 13 \\
\text { huruf h }\end{array}$ & $\begin{array}{l}\text { Sanksi administrasi berupa teguran } \\
\text { oleh pemerintah }\end{array}$ & $\begin{array}{l}\text { Pasal } 47 \\
\text { ayat (2) }\end{array}$ \\
\hline 6. & $\begin{array}{l}\text { Partai politik tidak } \\
\text { menyampakan laporan } \\
\text { penerimaan dan pengeluaran } \\
\text { dana bantuan keuangan partai } \\
\text { politik }\end{array}$ & $\begin{array}{l}\text { Pasal } 13 \\
\text { huruf i }\end{array}$ & $\begin{array}{l}\text { Sanksi administrasi berupa } \\
\text { penghentian pemberian bantuan } \\
\text { keuangan ke partai politik }\end{array}$ & $\begin{array}{l}\text { Pasal } 47 \\
\text { ayat (3) }\end{array}$ \\
\hline 7. & $\begin{array}{l}\text { Partai politik tidak memiliki } \\
\text { rekening khusus untuk } \\
\text { menampung dana kampanye } \\
\text { pemilu }\end{array}$ & $\begin{array}{l}\text { Pasal } 13 \\
\text { huruf j }\end{array}$ & $\begin{array}{l}\text { Sanksi administratif berupa teguran } \\
\text { oleh Komisi Pemilihan Umum }\end{array}$ & $\begin{array}{l}\text { Pasal } 47 \\
\text { ayat (4) }\end{array}$ \\
\hline 8. & $\begin{array}{l}\text { Partai politik menggunakan } \\
\text { fraksi di MPR, DPR, DPRD } \\
\text { Provinsi dan Kab/Kota untuk } \\
\text { sumber pendaan partai politik }\end{array}$ & $\begin{array}{l}\text { Pasal } 40 \text { ayat } \\
\text { (3) huruf e }\end{array}$ & $\begin{array}{l}\text { Sanksi administratif oleh badan/ } \\
\text { lembaga yang bertugas menjaga } \\
\text { kehormatan partai politik beserta } \\
\text { anggotanya }\end{array}$ & $\begin{array}{l}\text { Pasal } 47 \\
\text { ayat (5) }\end{array}$ \\
\hline 9. & $\begin{array}{l}\text { Partai politik berbadan hukum } \\
\text { menggunakan nama, lambang, } \\
\text { tanda gambar Pemerintah } \\
\text { Indonesia }\end{array}$ & $\begin{array}{l}\text { Pasal } 40 \text { ayat } \\
\text { (1) }\end{array}$ & $\begin{array}{l}\text { Sanksi administratif berupa } \\
\text { pembekuan kepengurusan oleh } \\
\text { pengadilan negeri }\end{array}$ & $\begin{array}{l}\text { Pasal } 48 \\
\text { ayat (1) }\end{array}$ \\
\hline
\end{tabular}




\begin{tabular}{|c|c|c|c|c|}
\hline 10. & $\begin{array}{l}\text { Kegiatan partai politik } \\
\text { bertentangan dengan UUD } \\
1945 \text { dan peraturan perundang- } \\
\text { undangan lainnya }\end{array}$ & $\begin{array}{l}\text { Pasal } 40 \text { ayat } \\
\text { (2) }\end{array}$ & $\begin{array}{l}\text { Sanksi administratif berupa } \\
\text { pembekuan sementara partai politik } \\
\text { oleh pengadilan negeri selama satu } \\
\text { tahun }\end{array}$ & $\begin{array}{l}\text { Pasal } 48 \\
\text { ayat (2) }\end{array}$ \\
\hline 11. & $\begin{array}{l}\text { Partai dibekukan sementara tapi } \\
\text { tetap melanggar Pasal } 40 \text { ayat } \\
\text { (2) }\end{array}$ & $\begin{array}{l}\text { Pasal } 48 \text { ayat } \\
\text { (3) }\end{array}$ & Pembubaran dengan putusan MK & $\begin{array}{l}\text { Pasal } 48 \\
\text { ayat (3) }\end{array}$ \\
\hline 12. & $\begin{array}{l}\text { Partai politik mendirikan badan } \\
\text { usaha atau memiliki saham } \\
\text { suatu badan usaha }\end{array}$ & $\begin{array}{l}\text { Pasal } 40 \text { ayat } \\
\text { (4) }\end{array}$ & $\begin{array}{l}\text { Sanksi administratif berupa } \\
\text { pembekuan sementara kepengurusan } \\
\text { partai serta aset dan sahamnya disita } \\
\text { untuk negara }\end{array}$ & $\begin{array}{l}\text { Pasal } 48 \\
\text { ayat (6) }\end{array}$ \\
\hline 13. & $\begin{array}{l}\text { Partai politik menganut } \\
\text { dan mengembangkan } \\
\text { serta menyebarkan ajaran } \\
\text { komunisme-marxisme- } \\
\text { leninisme }\end{array}$ & $\begin{array}{l}\text { Pasal } 40 \text { ayat } \\
\text { (5) }\end{array}$ & Pembubaran partai politik oleh MK & $\begin{array}{l}\text { Pasal } 48 \\
\text { ayat (7) }\end{array}$ \\
\hline 14. & $\begin{array}{l}\text { Jumlah sumbangan ke partai } \\
\text { politik melebihi ketentuan yang } \\
\text { ditetapkan undang-undang }\end{array}$ & $\begin{array}{l}\text { Pasal } 35 \text { ayat } \\
\text { (1) huruf b } \\
\text { dan huruf } c\end{array}$ & Sumbangan disita untuk negara & $\begin{array}{l}\text { Pasal } 49 \\
\text { ayat (3) }\end{array}$ \\
\hline
\end{tabular}

Sumber: Diolah oleh Penulis, 2018

UU No. 2/2008 jo UU No. 2/2011 lebih lengkap menjelaskan alasan atau sebab sebuah partai politik dijatuhkan sanksi. Permohonan pembubaran partai politik oleh MK hanya dapat dimohonkan oleh pemerintah (Jaksa Agung dan/atau menteri yang diberikan tugas oleh Presiden. ${ }^{25}$ Dalil yang dapat dipakai oleh pemerintah untuk mengajukan pembubaran partai politik ke MK dapat dilihat pada (i) Anggaran Dasar partai politik; (ii) Anggaran Rumah Tangga partai politik; dan (iii) laporan kegiatan partai politik. MK akan menerima dalil pemerintah terhadap tiga hal tersebut jika terbukti bertentangan dengan UUD 1945. Putusan MK atas pembubaran partai politik bersifat final dan mengikat. ${ }^{26}$ Akibat hukum dari pembubaran partai politik dapat berupa:

1) Pelarangan hak hidup partai politik dan penggunaan simbol partai politik tersebut diseluruh Indonesia;
2) Pemberhentian seluruh anggota DPR, DPRD Provinsi, dan DPRD Kabupaten/Kota yang berasal dari partai politik yang dibubarkan;

3) Pelarangan terhadap mantan pengurus partai politik yang dibubarkan untuk melakukan kegiatan politik; atau

4) Pengambilalihan oleh negara atas kekayaan partai politik yang dibubarkan. ${ }^{27}$

Berdasarkan uraian di atas mengenai pembubaran dan pembekuan partai politik dalam 3 (tiga) periode/masa pemerintahan orde lama, orde baru, dan reformasi, selanjutnya penulis perlu menjelaskan desain ideal dalam pembubaran partai politik yang telah divonis secara sah dan meyakinkan melakukan tindak pidana korupsi. Regulasi Indonesia mengenal pembubaran partai politik dalam tiga kriteria. Pertama, bubar apabila membubarkan diri atas keputusan sendiri.

\footnotetext{
Lihat Pasal 68 ayat (1) UU 8/2011 (Lembaran Negara Republik Indonesia Tahun 2011 Nomor 8, Tambahan Lembaran Negara Republik Indonesia Nomor 5226)

Jimly Asshiddiqie, Op.cit., hlm 113.

Pasal 10 ayat (2) Peraturan MK No. 12/2008.
} 
Kedua, menggabungkan diri dengan partai politik lain. Ketiga, dibubarkan oleh MK. ${ }^{28}$ Kriteria pertama dan kedua sepertinya sangat sulit diharapkan karena partai politik dibentuk bukan untuk dibubarkan maupun bergabung dengan partai politik lainnya-meski hal demikian dimungkinkan. ${ }^{29}$ Selanjutnya, keterangan tentang pembubaran partai politik oleh Mahkamah Konstitusi diatur lebih lanjut dalam Pasal 48 ayat (7) UU No. 2/2008 yang menyatakan, "Pelanggaran terhadap ketentuan sebagaimana dimaksud dalam Pasal 40 ayat (5) dikenai sanksi pembubaran Partai Politik oleh Mahkamah Konstitusi." Sedangkan bunyi Pasal 40 ayat (5) UU No. 2 Tahun 2008 adalah, "Partai Politik dilarang menganut dan mengembangkan serta menyebarkan ajaran atau paham komunisme/ marxisme-leninisme."

Ketentuan pembubaran partai politik melalui mekanisme MK sebagaimana diatur dalam UU No. 2/2008 sejatinya tidak banyak berubah jika mengacu ke undang-undang tentang partai politik sebelum dibentuknya MK. Bunyi Pasal 40 ayat (5) UU No. 2 Tahun 2008 persis dengan bunyi Pasal 19 ayat (5) UU No. 31/2002..$^{30}$ Mengacu ke bunyi Pasal 19 ayat (5) UU No. 32/2002 - yang ternyata mirip dengan bunyi Pasal 40 ayat (5) UU No. 2 Tahun 2008-Jimly Ashshiddiqie membuat tiga skenario pembubaran partai politik oleh
MK yang dirangkum dalam tabel sebagai berikut:

\section{Tabel 3}

Skenario Pembubaran Partai Politik

Berdasarkan UU No. 31 Tahun 2002 dan UU

No. 2 Tahun $\mathbf{2 0 0 8}^{31}$

\begin{tabular}{|c|c|}
\hline $\begin{array}{l}\text { Skenario } \\
\text { Pertama }\end{array}$ & $\begin{array}{l}\text { Partai politik yang melakukan } \\
\text { pelanggarandigugatpembekuan } \\
\text { oleh pemerintah ke pengadilan } \\
\text { negeri. Jika dikabulkan-dan } \\
\text { tidak dilakukan upaya hukum } \\
\text { kasasi ke Mahkamah Agung- } \\
\text { maka pemerintah dapat meng- } \\
\text { gunakan putusan pengadilan } \\
\text { tersebut untuk mengajukan } \\
\text { permohonan pembubaran } \\
\text { partai politik ke Mahkamah } \\
\text { Konstitusi }\end{array}$ \\
\hline $\begin{array}{l}\text { Skenario } \\
\text { Kedua }\end{array}$ & $\begin{array}{l}\text { Partai politik yang melakukan } \\
\text { pelanggaran langsung dimohon- } \\
\text { kanpembubarannyake Mahkamah } \\
\text { Konstitusi oleh pemerintah }\end{array}$ \\
\hline $\begin{array}{l}\text { Skenario } \\
\text { Ketiga }\end{array}$ & $\begin{array}{l}\text { Partai politik yang melakukan } \\
\text { pelanggaran dan digugat pembe- } \\
\text { kuan oleh pemerintah, tetapi } \\
\text { menang kasasi, tetap dimohonkan } \\
\text { pembubarannya ke Mahkamah } \\
\text { Konstitusi. }\end{array}$ \\
\hline
\end{tabular}

Sumber: Diolah oleh Penulis, 2018.

Selanjutnya, pembubaran partai politik oleh MK juga dapat dilakukan apabila partai melanggar ketentuan Pasal 40 ayat (2) UU No. $2 / 2008^{32}$ yang sebelumnya telah dijatuhi

28 Pasal 41 UU No. 2/2008 (Lembaran Negara Republik Indonesia Tahun 2008 Nomor 2, Tambahan Lembaran Negara Republik Indonesia Nomor 5189)

29 Contoh fusi partai yang pernah dilakukan di Indonesia misalnya mengacu ke TAP MPR No. IV/MPR/1973 tentang Garis-Garis Besar Haluan Negara (GBHN) hasil sidang MPR Tahun 1973 yang sebagian bunyinya menyatakan, “...Oleh karena itu dalam rangka membina kehidupan politik yang efektif dan efisien bagi pelaksanaan pembangunan, maka struktur, jumlah maupun sikap mental dari organisasi-organisasi kekuatan sosial politik tersebut, telah dapat mengelompokkan diri menjadi dua Partai Politik dan satu Golongan Karya..." Pasca-terbitnya TAP MPR tersebut, pada 10 Januari 1973, maka (i) Partai Nahdlatul Ulama/NU, Parmusi, Partai Sarekat Islam Indonesia/PSII, dan Perti berfusi menjadi Partai Persatuan Pembangunan. (ii) Partai Nasional Indonesia/PNI, Partai Kristen Indonesia/Parkindo, Partai Katolik, Partai Murba, dan IPKI berfusi menjadi Partai Demokrasi Indonesia (PDI). Lihat, Kuswanto, 2016, Konstitusionalitas Penyederhanaan Partai Politik: Pengaturan Penyederhanaan Partai Politik dalam Demokrasi Presidensial, Setara Press, Malang, hlm 153.

30 UU Nomor 31 Tahun 2002 tentang Partai Politik telah dihapus dan dinyatakan tidak berlaku dengan Undang-Undang Nomor 2 Tahun 2008 tentang Partai Politik.

31 Jimly Ashshiddiqie,Op.cit, hlm 114-116. Skenario tersebut juga dikaitkan dengan memasukkan pemerintah dalam alur pembubaran partai politik, yakni, dengan mendahului pemberian sanksi administratif dari pemerintah.

32 Bunyi Pasal 40 ayat (2) Undang-Undang Nomor 2 Tahun 2008 tentang Partai Politik selengkapnya berbunyi sebagai berikut:

"Partai Politik dilarang:

Melakukan kegiatan yang bertentangan dengan Undang-Undang Dasar Negara Republik Indonesia Tahun 1945 dan peraturan perundangundangan; atau

Melakukan kegiatan yang membahayakan keutuhan dan keselamatan Negara Kesatuan Republik Indonesia. 
sanksi administratif berupa pembekuan. ${ }^{33}$ Dengan demikian, proses pembubaran partai hanya dapat dilakukan melalui MK. ${ }^{34}$

UU No. 24/2003 menentukan bahwa yang diuji dari pembubaran partai politik adalah mengenai (i) ideologi; (ii) asas; (iii) tujuan; (iv) program; dan (v) kegiatan dari partai politik. ${ }^{35}$ Lima hal dari partai politik tersebut tentunya dapat dilihat dari peraturan dasar (Anggaran Dasar) $;{ }^{36}$ peraturan pelaksana dari peraturan dasar (Anggaran Rumah Tangga) $;{ }^{37}$ maupun program kerja dari partai politik. ${ }^{38}$ Jimly Ashshiddiqie mencatat, untuk mendukung pembuktian dugaan adanya pelanggaran yang dilakukan oleh partai politik, maka alat bukti yang dibutuhkan adalah:
a. Berkas Anggaran Dasar;
b. Berkas Anggaran Rumah Tangga;
c. Laporan dan surat yang menun- jukkan kegiatan partai politik;
d. Saksi;
e. Keterangan pihak; dan
f. Alat bukti lainnya. ${ }^{39}$

Pemerintah adalah pihak yang dapat memohonkan pembubaran partai. ${ }^{40}$ Sedangkan alasan untuk membubarkan partai tetap mengacu pada ketentuan yang diatur dalam Pasal 40 ayat (2) dan Pasal 40 ayat (5) UU No. 2/2008, yakni:
a. Partai
politik
melakukan kegiatan yang bertentangan

dengan UUD 1945;

b. Partai politik melakukan kegiatan yang bertentangan dengan peraturan perundangundangan;

c. Partai politik melakukan kegiatan yang membahayakan keutuhan NKRI;

d. Partai politik melakukan kegiatan yang membahayakan keselamatan NKRI;

e. Partai politik menganut ajaran atau paham komunisme/ marxisme-leninisme;

f. Partai politik mengembangkan ajaran atau paham komunisme/ marxisme-leninisme; dan

g. Partai politik menyebarkan ajaran atau paham komunisme/ marxisme-leninisme.

Dari tujuh alasan pembubaran partai tersebut, alasan "bertentangan dengan peraturan perundang-undangan" dapat digunakan sebagai pintu untuk memasukkan kriteria kejahatan khusus (extraordinary crime) sebagai alasan pembubaran partai politik. Dengan mengacu ke Pasal 1 angka 2 Undang-Undang Nomor 12 Tahun 2011 tentang Pembentukan Peraturan Perundang-undangan (selanjutnya ditulis UU No. 12/2011) yang berbunyi "Peraturan Perundang-undangan adalah peraturan tertulis yang memuat norma hukum yang mengikat secara umum dan dibentuk atau ditetapkan oleh lembaga negara atau pejabat

Pasal 48 ayat (3) Undang-Undang Nomor 2 Tahun 2008 tentang Partai Politik menjelaskan bahwa sanksi pembekuan yang dijatuhkan ke partai politik paling lama adalah 1 tahun sebagaimana ditentukan dalam Pasal 48 ayat (2) Undang-Undang Nomor 2 Tahun 2008 tentang Partai Politik.

34 Hal ini sesuai dengan Pasal 24C ayat (1) Undang-Undang Dasar Tahun 1945.

35 Lihat Pasal 68 ayat (2) UU No. 24/2003 (Lembaran Negara Republik Indonesia Tahun 2003 Nomor 98, Tambahan Lembaran Negara Republik Indonesia Nomor 4316).

36 Lihat Pasal 1 ayat (2) UU No. 2/2008 (Lembaran Negara Republik Indonesia Tahun 2008 Nomor 2, Tambahan Lembaran Negara Republik Indonesia Nomor 4801).

37 Lihat Pasal 1 ayat (3) UU No. 2/2008 (Lembaran Negara Republik Indonesia Tahun 2008 Nomor 2, Tambahan Lembaran Negara Republik Indonesia Nomor 4801).

38 Pasal 2 ayat (4) UU No. 2/2008 pada pokoknya menyatakan bahwa Anggaran Dasar partai politik setidaknya memuat (a) asas dan ciri partai politik; (b) visi dan misi partai politik; (c) nama, lambang, dan tanda gambar partai politik; (d) tujuan dan fungsi partai politik; (e) organisasi, tempat kedudukan, dan pengambilan keputusan; (f) kepengurusan partai politik; (g) peraturan dan keputusan partai politik; (h) pendidikan politik; dan (i) keuangan partai politik.

39 Jimly Ashshiddiqie, Op.cit., hlm 123.

40 Pasal 68 ayat (1) UU No. 2 Tahun 2008 (Lembaran Negara Republik Indonesia Tahun 2008 Nomor 2, Tambahan Lembaran Negara Republik Indonesia Nomor 4801). 
yang berwenang melalui prosedur yang ditetapkan dalam peraturan perundangundangan", maka alasan "bertentangan dengan peraturan perundang-undangan" dapat dimaknai lebih luas lagi. Jenis dan hierariki peraturan perundang-undangan yang meliputi:
a. UUD 1945;
b. TAP MPR;
c. Undang-Undang/Peraturan Pemerintah Pengganti Undang- Undang;
d. Peraturan Pemerintah;
e. Peraturan Presiden;
f. Peraturan Daerah Provinsi; dan
g. Peraturan Daerah Kabupaten/ Kota. ${ }^{41}$

Dapat menjadi alas untuk mengajukan permohonan pembubaran partai. Bahkan apabila mengacu ke Pasal 8 ayat (1) UU No. 12/2011 yang mengakui jenis peraturan perundang-undangan sebagaimana disebut dalam Pasal 7 ayat (1) UU No. 12/2011, ${ }^{42}$ maka peraturan perundang-undangan selain yang disebut di atas dapat pula dijadikan sebagai alat uji untuk membubarkan partai politik apabila kata "peraturan perundangundangan" dalam frasa "bertentangan dengan peraturan perundang-undangan" yang tertera di Pasal 40 ayat (2) UU No. 2/2008 diartikan sesuai dengan Pasal 7 ayat (1) dan Pasal 8 ayat (1) UU No. 12/2011. Untuk mendapatkan kekhususan, alangkah baik apabila frasa "bertentangan dengan peraturan perundang-undangan" dalam Pasal 40 ayat (2) UU No. 2/2008 diubah dengan memasukkan ketentuan yang lebih khusus, misalnya, dengan menyebut "bertentangan dengan undang-undang pemberantasan tindak pidana korupsi, pemberantasan terorisme, pemberantasan pencucian uang" dan seterusnya.

Partai politik sebagai organisasi yang dibentuk oleh sekelompok warga ${ }^{43}$ mengindikasikan bahwa pertanggungjawaban pidana terhadap partai politik atas tindak pidana korupsi dapat dikenakan ke partai politik itu sendiri dan/atau ke sekelompok warga yang membentuk atau menjalankan partai politik tersebut. Dasarnya adalah Pasal 1 angka 3 jo Pasal 1 angka 1 UndangUndang Nomor 31 Tahun 1999 tentang Pemberantasan Tindak Pidana Korupsi (selanjutnya ditulis UU No. 31/1999). ${ }^{44}$ Pertanggungjawaban pidana terhadap partai politik harus dibedakan antara subjek yang ada dalam partai politik dengan partai politik itu sendiri. Berdasarkan Pasal 2 ayat (4) huruf f UU No. 2/2008 jo Pasal 2 ayat (4) huruf $\mathrm{f}$ UU No. 2/2011, Anggaran Dasar partai politik memuat kepengurusan partai politik. Dengan demikian, pertanggungjawaban pidana terhadap pengurus partai politik dengan partai politik itu sendiri mesti dibedakan. Apabila Pasal 2 ayat (4) huruf a UU No. 2/2008

41 Pasal 7 ayat (1) UU No. 12/2011.

42 Jenis peraturan perundang-undangan yang disebut dalam Pasal 8 ayat (1) Undang-Undang Nomor 12 Tahun 2011 tentang Pembentukan Peraturan Perundang-undangan, meliputi Peraturan MPR; Peraturan DPR; Peraturan DPD; Peraturan MA; Peraturan MK; Peraturan BPK; Peraturan KY; Peraturan Bank Indonesia; Peraturan Menteri; Peraturan badan yang dibentuk dengan undang-undang; Peraturan lembaga yang dibentuk dengan undang-undang; Peraturan komisi yang dibentuk dengan undang-undang; Peraturan badan yang dibentuk oleh pemerintah atas perintah undang-undang; Peraturan lembaga yang dibentuk pemerintah atas perintah undang-undang; Peraturan komisi yang dibentuk pemerintah atas perintah undang-undang; Peraturan DPRD Provinsi; Peraturan Gubernur; Peraturan DPRD Kabupaten/Kota; Peraturan Bupati/Walikota; dan Peraturan desa atau yang setingkat.

43 Pasal 1 angka 1 Undang-Undang Nomor 2 Tahun 2008 tentang Partai Politik mendefinisikan Partai Politik sebagai "organisasi yang bersifat nasional dan dibentuk oleh sekelompok warga negara Indonesia secara sukarela atas dasar kesamaan kehendak dan cita-cita untuk memperjuangkan dan membela kepentingan politik anggota, masyarakat, dan negara, serta memelihara keutuhan Negara Kesatuan Republik Indonesia berdasarkan Pancasila dan Undang-Undang Dasar Republik Indonesia Tahun 1945."

44 Pasal 1 angka 3 Undang-Undang Nomor 31 Tahun 1999 tentang Pemberantasan Tindak Pidana Korupsi berisi ketentuan bahwa "Setiap orang adalah orang perseorangan atau termasuk korporasi." Sedangkan Pasal 1 angka 1 Undang-Undang Nomor 31 Tahun 1999 tentang Pemberantasan Tindak Pidana Korupsi mengatur bahwa "Korporasi adalah kumpulan orang dan/atau kekayaan yang terorganisasi baik merupakan badan hukum maupun bukan badan hukum." 
jo Pasal 2 ayat (4) huruf a UU No. 2/2011

dihubungkan dengan Pasal 1 angka 3 jo

Pasal 1 angka 1 UU No. 31/1999, maka akan diperoleh kelompok pertanggungjawaban partai politik dalam tindak pidana korupsi sebagai berikut:

Tabel 4

Perbandingan Pengaturan Pertanggungjawaban Partai Politik

\begin{tabular}{lll}
\hline \multicolumn{1}{c}{ UU Partai Politik } & $\begin{array}{c}\text { UU Pemberantasan } \\
\text { Korupsi }\end{array}$ & \multicolumn{1}{c}{ Kelompok Pertanggungjawaban Pidana } \\
\hline $\begin{array}{l}\text { Pasal 2 ayat (4) huruf a UU } \\
\text { No. 2/2008 jo Pasal 2 ayat } \\
\text { (4) huruf a UU No. 2/2011 }\end{array}$ & $\begin{array}{l}\text { Pasal 1 angka 3 jo } 1 \text { angka 1 UU } \\
\text { No. 31/1999 }\end{array}$ & $\begin{array}{l}\text { Pertanggungjawaban pidana pengurus partai } \\
\text { politik (orang perorangan) }\end{array}$ \\
\hline
\end{tabular}

Sumber: Diolah oleh Penulis, 2018.

Pertanggugjawaban pidana partai politik yang dimasukkan dalam kategori korporasi mengikuti tata cara yang ditetapkan oleh MA melalui Peraturan Mahkamah Agung Nomor 13 Tahun 2016 tentang Tata Cara Penanganan Perkara Tindak Pidana oleh Korporasi (selanjutnya ditulis Perma No. 13/2016). Korporasi dalam Perma ini diartikan dengan "kumpulan orang dan/ atau kekayaan yang terorganisir, baik merupakan badan hukum maupun bukan badan hukum." ${ }^{45}$ Melalui bunyi ketentuan korporasi itu, maka syarat dari korporasi adalah adanya sekumpulan orang dan kumpulan tersebut dapat berbadan hukum maupun tidak berbadan hukum. Partai politik sendiri ditentukan harus berbadan hukum. ${ }^{46}$ Meski demikian, terdapat kelemahan jika mengartikan partai politik sebagai korporasi berdasarkan Perma No. 13/2016. Sebab, Pasal 1 angka 8 Perma tersebut menuliskan tindak pidana oleh korporasi adalah, “... tindak pidana yang dapat dimintakan pertanggungjawaban pidana korporasi sesuai dengan undang-undang yang mengatur korporasi." Sampai penelitian ini ditulis, pemerintah (DPR dan/atau Presiden) belum membuat undang-undang khusus tentang korporasi. Aturan mengenai korporasiatau pertanggungjawaban pidana terhadap korporasi-diatur berserakan dalam berbagai peraturan perundang-undangan. Oleh karena itu, yang digunakan untuk mengukur korporasi adalah prinsip umum tentang korporasi.

Pada 2013, Pusat Kajian Antikorupsi Fakultas Hukum Universitas Gadjah Mada (Pukat) melakukan penelitian bertajuk "Pemidanaan Korporasi atas Tindak Pidana Korupsi di Indonesia." ${ }^{27}$ Sebagian hasil penelitian menyatakan,

“...untuk melihat dan menilai sebuah korporasi, setidaknya dibutuhkan tiga batasan. Pertama, legal personality. Ada unsur dalam sebuah korporasi yang memiliki otoritas mengelola aset atau membuat perjanjian. Kedua,

Lihat Pasal 1 angka 1 Perma No. 13 Tahun 2016 tentang Tata Cara Penanganan Perkara Tindak Pidana oleh Korporasi. Namun demikian, sayangnya pengertian korporasi dalam ketentuan selanjutnya dimaknai lebih khusus dengan "perusahaan".

46 Pasal 3 ayat (1) Undang-Undang Nomor 2 Tahun 2008 tentang Partai Politik berbunyi, "Partai Politik harus didaftarkan ke Departemen untuk menjadi badan hukum." Ketentuan demikian sedikit berubah dalam Pasal 3 ayat (1) Undang-Undang Nomor 2 Tahun 2011 tentang Perubahan Atas Undang-Undang Nomor 2 Tahun 2008, yakni, "Partai Politik harus didaftarkan ke Kementerian untuk menjadi badan hukum." Namun demikian, substansi dari dua pasal tersebut tetap sama, yaitu, partai politik adalah sebuah badan hukum.

47 Hifdzil Alim, et.al., 2013, Pemidanaan Korporasi atas Tindak Pidana Korupsi di Indonesia, Pusat Kajian Antikorupsi FH UGM, Yogyakarta. 
limited liability. Harus dipisahkan antara aset korporasi dan aset individu dalam korporasi tersebut. Ketiga, delegated management. Terdapat struktur yang diisi oleh masing-masing subjek yang memiliki kewenangan masing-masing." 48

Dengan menggunakan pendekatan yang diurai oleh Pukat, maka perihal selanjutnya yang ditentukan dari partai politik apakah dapat dikategorikan sebagai korporasi adalah mendeteksi batasan korporasi (legal personality, limited liability, dan delegated management) di dalam partai politik. Perihal demikian dapat, salah satunya, dibaca dari pengelolaan keuangan partai politik.

Pada 2014, Badan Pembinaan Hukum Nasional melakukan riset bertajuk "Akuntabilitas Pendanaan Partai Politik Dalam UU No. 2/ 2011".49 Sebagian temuan riset berisi bahwa partai politik memiliki dua rekening bank. Satu rekening difungsikan untuk kas umum partai politik. Sedangkan rekening lainnya dimanfaatkan untuk menampung dana kampanye. ${ }^{50}$ Penelitian tersebut tidak sampai mengarah ke pengelolaan aset masing-masing partai. Akan tetapi, dengan mengacu bahwa terdapat pemisahan kepemilikan dana untuk partai-melalui kas umum partai politik maupun dana untuk kampanye-dengan aset para pengurus partai, maka prinsip umum korporasi yang berupa limited liability (memisahkan pengelolaan uang partai dengan pengurus) dan delegated management (susunan kepengurusan partai) telah terpenuhi dalam partai politik. Selanjutnya, apabila pelaksanaan perjanjian didelegasikan ke struktural tertentu dalam partai politik berdasarkan AD/ART-nya, maka prinsip limited liability telah juga terpenuhi.

Dengan demikian, memeriksa pertanggungjawaban pidana terhadap partai politik dapat dianalogikan dengan memeriksa pertanggungjawaban pidana terhadap korporasi sebagaimana diatur dalam Perma No. 13/2016. Alasan pemidanaan dan tata cara pemeriksaan terhadap pertanggungjawaban pidana partai politik atas tindak pidana korupsi secara mutatis mutandis mengikuti ketentuan yang sebagaimana diatur dalam Perma No. 13/2016. Menjadi sangat harus diperhatikan bahwa pertanggungjawaban pidana terhadap partai politik tidak dapat dibebankan karena perbuatan pidana pribadi anggota yang tidak dilakukan untuk dan atas nama, atau tidak mendapatkan mandat sebelumnya, dari partai politik. Baik dalam ruang lingkup publik maupun privat. Ketentuan ini diakui sebagai ketentuan universal dari penyelenggaraan partai politik. $^{51}$ Sepanjang anggota yang melakukan pidana bukan untuk dan atas nama partai politik, maka partai tidak bisa dimintai pertanggungjawaban pidana. Hal ini sekaligus untuk menjamin hak asasi manusia dalam berpolitik.

\section{Kesimpulan}

Berdasarkan hasil penelitian, maka dapat disimpulkan dua hal sebagai berikut, yaitu Pertama, Partai politik dapat dikategorikan sebagai korporasi sebagaimana diatur dalam UU No. 31/1999. Ancaman hukuman yang dapat dijatuhkan ke partai

Ibid., hlm 7.

Penelitian dilaksanakan di bawah pimpinan Rooseno, SH., MHum, Badan Pembinaan Hukum Nasional Kementerian Hukum dan HAM Republik Indonesia, 2014.

${ }^{5} \quad$ Ibid., hlm 56.

51 Venice Commision, Compilation of Venice Commission Opinions and Reports Concerning Political Parties, diterbitkan pada 15 Maret 2016 di Strasbourg, hlm 55. European Commission for Democracy Through Law atau lebih dikenal dengan Venice Commision dalam rapat plenonya pada 11-12 Maret 2016 menyatakan, "A Political party as a whole cannot be held responsible for the individual behaviour of its members not authorised by the party within the frame of political/public and party activities." 
politik sebagai korporasi yang diduga melakukan tindak pidana korupsi adalah pidana denda dengan ketentuan maksimum ditambah sepertiga serta pidana tambahan. Kedua, Partai politik yang telah divonis secara sah dan meyakinkan melakukan tindak pidana korupsi kemudian dimohonkan oleh pemerintah ke MK supaya dibubarkan. Ketiga, Masih kurang 1 kesimpulannya

\section{DAFTAR PUSTAKA}

\section{A. Buku}

Ali, Mahrus, 2016. Hukum Pidana Korupsi, UII Press. Yogyakarta.

Alim, Hifdzil, et al., 2013, Pemidanaan Korporasi atas Tindak Pidana Korupsi di Indonesia, Pusat Kajian Antikorupsi FH UGM, Yogyakarta.

Asshiddiqie, Jimly, 2005, Kemerdekaan Berserikat, Pembubaran Partai Politik, dan Mahkamah Konstitusi, Konstitusi Press, Jakarta.

Hiariej, Eddy O.S., 2018, Prinsip-prinsip Hukum Pidana, Cahaya Atma Pustaka, Yogyakarta.

Keijzer, Schaffmeister, N., et.al., 2010, Hukum Pidana, Citra Aditya Bakti, Bandung.

Kuswanto, 2016, Konstitusionalitas Penyederhanaan Partai Politik: Pengaturan Penyederhanaan Partai Politik dalam Demokrasi Presidensial, Setara Press, Malang.

Muladi, et.al.,, 2010, Pertanggungjawaban Pidana Korporasi, Kencana Prenada Media, Jakarta.

Noer, Deliar, 1987, Partai Islam di Pentas Nasional 1945-1965, Pustaka Utama Grafiti Jakarta

Notosusanto, Nugroho, 1991. Tercapainya Konsensus Nasional 1966-1969, Balai Pustaka, Jakarta.

Rooseno, 2014, Badan Pembinaan Hukum Nasional Kementerian Hukum dan HAM Republik Indonesia. Jakarta.

Safa'at, Muchamad Ali, 2011, Pembubaran Partai Politik, Pengaturan dan Praktik Pembubaran Partai Politik Dalam Pergulatan Republik, Rajawali Press, Jakarta.

Syaifullah, 1997, Gerak Politik Muhammadiyah Dalam Masyumi, PT Pustaka Utama Grafiti, Jakarta.

\section{B. Artikel Jurnal}

Widayati, "Pembubaran Partai Politik Dalam Sistem Ketatanegaraan Indonesia", Jurnal Hukum, Vol. XXXVI, No. 2, Agustus 2011.

\section{Peraturan Perundang-undangan}

Ketetapan MPRS Nomor XXV/MPRS/1966 tentang Pembubaran Partai Komunis Indonesia, Pernyataan Sebagai Organisasi Terlarang Diseluruh Wilayah Indonesia bagi Partai Komunis Indonesia dan Larangan Setiap Kegiatan atau Menyebarkan atau Mengembangkan Faham atau Ajaran Komunisme/Marxisme/Leninisme.

Undang-Undang Nomor 31 Tahun 1999 tentang Pemberantasan Tindak Pidana Korupsi (Lembaran Negara Republik Indonesia Tahun 1999 Nomor 140, Tambahan Lembaran Negara Republik Indonesia Nomor 387).

Undang-Undang Nomor 20 Tahun 2001 tentang Perubahan Atas Undang-Undang Nomor 31 Tahun 1999 tentang Tindak Pidana Korupsi (Lembaran Negara Republik Indonesia Tahun 2001 Nomor 134, Tambahan Lembaran Negara Republik Indonesia Nomor 4150).

Undang-Undang Nomor 24 Tahun 2003 tentang Mahkamah Konstitusi (Lembaran Negara Republik Indonesia Tahun 2003 Nomor 98, Tambahan Lembaran Negara Republik Indonesia Nomor 4316).

Undang-Undang Nomor 2 Tahun 2008 tentang Partai Politik (Lembaran Negara Republik Indonesia Tahun 2008 Nomor 2, Tambahan Lembaran Negara Republik Indonesia Nomor 4801).

Undang-Undang Nomor 2 Tahun 2011 tentang 
Perubahan Atas Undang-Undang Nomor 2

Tahun 2008 tentang Partai Politik (Lembaran

Negara Republik Indonesia Tahun 2011

Nomor 8, Tambahan Lembaran Negara

Republik Indonesia Nomor 5189).

Undang-Undang Nomor 8 Tahun 2011 tentang

Perubahan Atas Undang-Undang Nomor 24

Tahun 2003 tentang Mahkamah Konstitusi

(Lembaran Negara Republik Indonesia

Tahun 2011 Nomor 70, Tambahan Lembaran

Negara Republik Indonesia Nomor 5226).

Undang-Undang Nomor 12 Tahun 2011 tentang

Pembentukan Peraturan Perundang-

undangan (Lembaran Negara Republik

Indonesia Tahun 2011 Nomor 82, Tambahan

Lembaran Negara Republik Indonesia Tahun 1959 yang telah dicetak ulang).

Penetapan Presiden Nomor 7 Tahun 1959

tentang Syarat-syarat dan Penyederhanaan Kepartaian (Lembaran Negara Republik Indonesia Tahun 1960 Nomor 79, Tambahan Lembaran Negara Nomor 2016).

Peraturan Presiden Nomor 13 Tahun 1960 tentang Pengakuan, Pengawasan, dan Pembubaran
Partai-Partai (Lembaran Negara Republik Indonesia Tahun 1960 Nomor 79, Tambahan Lembaran Negara Nomor 2016).

Peraturan Presiden Nomor 25 Tahun 1960 tentang Perubahan Atas Perpres No. 13/1960 tentang Pengakuan, Pengawasan, dan Pembubaran Partai Politik (Lembaran Negara Republik Indonesia Tahun 1960 Nomor 139, Tambahan Negara Tahun 1960 Nomor 2092).

Keputusan Presiden Nomor 200 Tahun 1960 tentang Pembubaran Partai Masyumi.

Keputusan Presiden Nomor 201 Tahun 1960 tentang Pembubaran Partai Sosialis Indonesia.

Keputusan Presiden Nomor 291 Tahun 1965 tentang Pembekuan terhadap Partai Murba.

Peraturan Mahkamah Konstitusi Nomor 12 Tahun 2008 tentang Prosedur Beracara dalam Pembubaran Partai Politik.

Peraturan Mahkamah Agung Nomor 13 Tahun 2016 tentang Tata Cara Penanganan Perkara Tindak Pidana oleh Korporasi.

\section{Dokumen Lain}

Surat Dakwaan KPK Nomor DAK-15/24/02/2017. 